International Journal of Linguistics, Literature and Translation

ISSN: 2617-0299 (Online); ISSN: 2708-0099 (Print)

DOI: $10.32996 / \mathrm{ijllt}$

Journal Homepage: www.al-kindipublisher.com/index.php/ijllt

IJLLT

\title{
Teachers' (De)Motivation During COVID-19 Pandemic: A Case Study from Nepal
}

\author{
Laxmi Prasad Khanal ${ }^{1}$ 8(D) , Samikshya Bidari ${ }^{2}$ (iD and Bendaoud NADIF ${ }^{3}$ (D) $\Delta$ \\ ${ }^{1}$ Lecturer at Texas International College, Nepal \\ ${ }^{2}$ Ph.D. Scholar, English Language Education, Kathmandu University, Nepal \\ ${ }^{3} \mathrm{Ph}$ D. Candidate, English Department, Moulay Ismail University, Meknes, Morocco \\ $\triangle$ Corresponding Author: Bendaoud Nadif, E-mail: bendaoudnadif@gmail.com
}

\section{ARTICLE INFORMATION}

Received: May 08, 2021

Accepted: June 11, 2021

Volume: 4

Issue: 6

DOI: $10.32996 /$ ijllt.2021.4.6.10

\section{KEYWORDS}

Continuous professional development, demotivation, dissatisfaction, low wages, motivation

\section{ABSTRACT}

The COVID-19 pandemic has produced havoc in the world and Nepal is no exception. A transition from an in-person classroom to online classroom has been daunting for the students and teacher's motivation level. The impact of teacher morale is often neglected by policymakers and all the stakeholders themselves, which may lead to teachers' lack of motivation or "demotivation". Teachers' demotivation is an emotional, cognitive, sociocultural and psychological state that leads to exhaustion, depersonalization, burnout, decreased teacher achievement and self-worth stress. This study aimed to investigate the factors that supported and hindered Nepalese EFL teachers' motivation levels in their classrooms. A qualitative case study was employed as a research design. Four EFL secondary level teachers teaching at private schools in Kathmandu Valley were selected for this study. The teacher participants were chosen via a systematic random sampling procedure. The data was analyzed and interpreted using a thematic approach, employing survey questionnaires, teachers' interviews, and classroom observation as data collection instruments. The results of this study revealed that EFL teachers in private schools are intrinsically and extrinsically demotivated. The factors that demotivate these teachers include low wages, lack of continuing professional development, students' disruptive behaviors, job insecurity, and fewer holidays.

\section{Introduction}

Dissatisfactory remuneration with emotional exhaustion is the primary predictor of teacher burnout. It directly relates to negative interactions with students and influences overall teaching and the learning process negatively (Pant, 2018). This research aimed to highlight some of the major academic and non-academic factors contributing to teachers' demotivation during the COVID-19 pandemic-related online classroom. Unexpected transition from physical to the online classroom has been daunting for the student's and the teacher's motivation level. Harmer (2007, p. 98) defines motivation as "some internal drive which pushes someone to do something to achieve something." Without a motivated teacher, it is impossible to observe students demonstrating motivation in the classroom. Very few studies have been carried out on teachers' motivation in Nepal amid COVID-19. This study aimed to investigate the factors that supported and hindered Nepalese EFL teachers' motivation levels in their classrooms. A qualitative case study was employed as a research design. Four EFL secondary level teachers teaching at private schools in Kathmandu Valley were selected for this study. The teacher participants were chosen via systematic random sampling procedure. The data were analyzed and interpreted using a thematic approach, employing survey questionnaires, teachers' interviews, and classroom observation as data collection instruments. The study seeks to find answers to the following questions:

1)-What are the factors demotivating EFL teachers in Nepalese context?

2)-What are the implications of teacher motivation for EFL teachers' professional development?

\section{K C AL-KINDI CENTER \\ $\mathbf{R}$ D FOR RESEARCH AND DEVELOPMENT}

Your gateway to world-class research

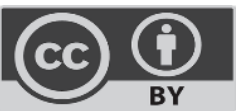

Published by Al-Kindi Center for Research and Development, London, United Kingdom. Copyright (c) the author(s). This open access article is distributed under a Creative Commons Attribution (CC-BY) 4.0 license 


\section{Literature Review}

Motivation is a stimulant that drives individuals towards excellence. Gheralis- Roussos, E. (2003) defines motivation as a set of forces that leads people to behave in particular ways. It is an inner state that energizes, moves, channels, and sustains behavior towards a goal. Therefore, motivation is considered to be the most significant aspect in achieving the desired goal. Teacher motivation (TM) is one of the highly researched areas (Han \& Yin, 2016). Safari (2021) stated that "teachers communicate with large numbers of students, parents, and principal" - thereby each has different demands and problems. As stated by Monyatsi," (2006), there are three main factors which have an important role in constructing teachers' self-efficacy. The first factor is the teachers' positive teaching experiences particularly at the beginning of their job. The second factor is observing other teachers' effective teaching practices. The third and last factor involves convincing teachers about their effectiveness or potential effectiveness by offering positive and constructive feedback.

Similarly, Sinclair (2008) postulated that if teachers are to be sustained in teaching for a long time and if they are satisfied with the desired facilities, then they are expected to be teaching with high enthusiasm and dedication. Bidari (2021), claims that teachers play an important role in molding the behaviors of the learners. They often make positive changes by influencing individuals' lives and learning tendencies (Pan \& Say, 2017). Indeed, teachers can effectively contribute to a paradigm shift in society as they are considered the change agents (Nadif \& Benattabou, 2021). A common impression of the teaching force is that of the overworked and dissatisfied body of professionals, who have to cope with low status, low pay, discipline problems, large class size and imposed curricula (Gheralis- Roussos, 2003). As stated by Johnson et al. (2005), the teaching profession is one of the stressful jobs.

From this, it is coincided that teachers' demotivation commences when they express dissatisfaction due to certain problems. Aslam and Sarwar (2010) argued that motivation is a central and vital component that is a key contributor to an employee's job satisfaction. The only means of knowing whether the teachers are motivated is through the degree to which they are content at the moment. Furthermore, teachers are known to be the developers of a positive and progressive society in any country. It is, therefore, necessary to have highly motivated teachers.

Teacher motivation sounds like a buzzword at present in the field of teacher professional development. It is closely related to several variables in education, such as student motivation, educational reform, teaching practice, teachers' psychological fulfillment and well- being (Han \& Yin, 2016). This means TM is multidimensional in nature. Research on teacher motivation has developed and expanded since the late 1990s, and the last decade has witnessed a marked increase in the literature relevant to the area of teacher motivation research across various socio- cultural contexts (ibid). A renewed research interest in teachers' motivation to teach and to remain teaching in the past decade has highlighted possible causes of the existing and potential teacher shortages as early teacher attrition, teaching force ageing, imbalance of high demand with less reward, limited career opportunities, less job security and low prestige (Watt et al. 2012, as cited in Han \& Yin, 2016). In other words, it is noticed that several teachers at present are found to be quitting teaching, due to which there has appeared to be a shortage of teachers.

Teacher motivation is helpful for administrators to determine how to attract potential teachers and how to retain them in teaching. Similarly, Dornyei and Ushioda (2011) highlight two dimensions of teacher motivation, viz., the motivation to teach and motivation to remain in the profession. This shows that the teachers should be motivated to make teaching effective; therefore, they can remain in teaching for longer spans.

Years of in-service teacher motivation studies have a strong tradition in the research fields, like influencing teacher motivation and teaching effectiveness, the relationship between teacher motivation and student motivation, etc. (Han \& Yin, 2016). Jesus and Lens (2005) argue that motivated teachers are more likely to work for educational reform and legislation. This means motivated teachers are highly dedicated, committed and enthusiastic for professional acceleration. Teacher demotivation is a major obstacle in the teaching and learning process. A demotivated teacher is a teacher who is once motivated but loses interest for some reason (Kiziltepe, 2008). Teacher motivation is very critical in achieving academic excellence. Bishaya (1996) argues that the teaching profession ranks high on the success list of society. This means that teaching is found to have been viewed as a prestigious profession in society. Teachers are mentors, life shapers, destiny shapers, and they must be prepared to undertake the task put into their hands diligently.

Teachers must be motivated through various ways, like seminars, workshops, timely payment of salary, wage, physical facilities, etc. It is believed that we cannot expect academic excellence from the demotivated teachers, while it is possible only if the teachers are utterly intrinsically and extrinsically motivated.

Teachers are considered to be the destiny shapers of the students. Nawaz and Yasin (2015) opine that teachers are essential for developing the future of students. It is assumed that it is teachers who can unquestionably mold the destiny of the students. Hence, it is mandatory to have a good rapport between the teachers and the students. 
TM is supportive in achieving institutional and individual goals. Indeed, a motivated teacher can be conducive to flourishing the institutions and putting various planning and policies into force. On top of that, as English is a global language today, it is crucial to motivate English language teachers in the EFL countries like Nepal.

\section{Research Methodology}

The present study is qualitative in nature and the data were collected using in-depth teachers' interview and a research instrument. Before designing the interview, a survey questionnaire was distributed with ethical consideration, and an informed consent form to be signed through Facebook teachers group and emails. Only four teachers who were interested in participating in the interview were contacted by WhatsApp, Viber and messenger as mentioned communicating media choice collected in the google form. Teachers were given codes as T1, T2, T3 and T4 in this article. The research site was Kathmandu Valley. Further, the collected data were analyzed and interpreted thematically based on Listen -and -Note technique.

\section{Data-analysis and interpretation}

The analysis presented the general and specific themes. The headings are followed by the examples of the data and their analysis and interpretation. This has been done to critically analyze and interpret how and why the teachers are demotivated to teach at private schools in Nepal. The data are analyzed and interpreted under the two broader headings as follows:

\subsection{Academic factors}

Academic factors are those factors that are responsible for demotivating the teachers within the academic site. Regarding this study, those factors for the cause of which the people belonging to a particular academy are involved. Therefore, in this section, some of the themes belonging to this category have been generated based on the responses of $4 \mathrm{EFL}$ secondary level institutional teachers, which are analyzed and interpreted theme-wise as follows:

\subsection{Unsatisfactory Remuneration}

This theme is generated from the teachers' narratives that exhibit that institutional EFL teachers were demotivated due to low salary payment, partial payment, delayed payment. Regarding this, teacher T1 mentioned:

I have been involved in this field for the last eight years...and in these eight years I have not been able to earn even a single penny ...no saving at all...neither prestige ...nothing.... the salary that the school is paying me is not sufficient for me even to fulfill my basic needs......you know.... I do have a family, and there are altogether four members, including me...

From this extract of teacher A's response, he is likely to imply that he has been teaching for the last eight years, but pathetically he has not been able to save money, neither has he been able to have a quality of life. Due to this, he was frustrated with teaching and said that he was planning to go for other options apart from teaching at institutional schools. In a similar vein, teacher B stated:

Umm..... actually... I am not much satisfied because of the institutional organization... when I work here ......they give me some low salary, but that salary is from my hard work...because I have to work here for a long time ...from morning to evening.... from 6 a.m. to 6 p.m. ... almost 12 hours... so 12 hours of work is too much for us to get that much salary. So......in that way, I am not satisfied...

From the T2's response, it is further clear that he was also extremely demotivated to teach at institutional schools. Even if he worked from morning to evening, he is fully dedicated and committed. Hence, he could not feel happy regarding remuneration. From this, it can be interpreted that the school administration used him inadequately and ineffectively. Furthermore, teacher $C_{\text {, }}$ regarding the same factor, articulated:

I am not getting enough salary according to my labor .......sometimes I do not get salary in time...they pay me little by little.... sometimes they pay Rs. 500/1000/... 10,000......not full salary...that truly demotivates me...

I found teacher C's response very pathetic. He said that even though he worked harder without considering his personal life, he was found to be paid low. He also said that he was not being paid regularly but bit by bit as if he was a labor who was working only for wages. Moreover, I also talked to another teacher who stated...... salary is not paid on a regular basis due to which I feel difficulty even running my livelihood...... and the money I receive from my school is not sufficient for me to live a happy life....

Similarly, T4 is felt frustrated from teaching at institutional schools since the salary he receives is not sufficient even to run his livelihood and have a happy and prosperous life.

From the discussion above, it can be deduced that all the teachers participating in the interview were found to be completely demotivated due to low salaries. All the teachers said they wanted to go for other options apart from institutional teaching because the salary they received was insufficient even to fulfill their day-to-day problems. Therefore, if they are to be sustained in teaching, they should be pleased with satisfactory remuneration; in turn, they will be teaching earnestly and assiduously.

\subsection{Lack of Professional Development Programs}


This theme is extracted from the EFL teachers' narratives. This shows that the EFL institutional teachers were demotivated due to the lack of professional development programs at the schools where they teach. All the participant teachers said they had never got a chance to attend any professional development activities, like seminars, workshops, webinars, and conferences. Regarding this, teacher A reported:

Yeah... I have attended a few of the conferences...leadership conferences..... I have attended teachers' conferences.... most of the time, the school administrator sends us, and they send us... with the intention of going there and taking such classes.... we will further be enhanced ... you know like.... further strengthened ... and with the strengthened mentality and attitude. When we come back and go to the classroom that will improve our performance....so most of the time the school seems to be paying for such conferences.

This excerpt shows that T1 was demotivated because he states that the school administration never organizes any professional development programs; if he is willing to attend such events, he has to be funded by himself. He goes on to tell that if any other parties are organizing such events, the school seems to be in a position to send the teachers to the event with an intention that they will, in turn, improve teaching. In a similar vein, T3 stated:

Yes... I have attended many sessions, like seminars, workshops, conferences ...sometimes I paid myself...and sometimes institution also helped me .... but most of the time, I paid myself... for professional development...just to know the experiences of other teachers...

From T4's response, it seems that he was found to be demotivated because he is not financially supported; if he wants, he has to pay by himself. He says that he is interested in participating in such events to get to know the teachers' experiences regarding English language teaching. In this regard, T4 added:

.......and another important thing is that they never organize the professional development sessions, like training, workshops, seminars, conferences...but I feel like being trained....so I attend such events by paying myself.... this frustrates me .......

From T4 response as well, it sounds that he is demotivated to teach at institutional schools because he insists that he longs to be trained through different professional development programs, such as seminars, workshops. Yet, the school turns back to send him and finally keeps his job at risk; he says he goes to attend because he says these events are essential in the professional career.

To conclude, based on all the teachers' narratives reported and discussed above, it can be said that all the teachers teaching at the institutional academics were found to be frustrated, in turn, demotivated because the schools never send the teachers to the professional development events. Therefore, it is imperative to say that they should be financially supported by themselves.

\subsection{Less Holidays}

Holidays are considered to be significant for the teachers to enjoy their personal life. However, the teacher respondents chosen for the interview were found to be deprived of holidays and different leaves at institutional schools. Due to the scarcity or absence of holidays, teachers ended up being demotivated to teach effectively. In this sense, one of the teacher respondents A stated:

Altogether 12 days...Ya.... I mean....in a year, we have been granted 12 days as holidays...if divided mathematically ...per month a day....and if we remain absent for more than one day, our salary will be deducted .... ah ...I don't feel happy.... these are a few of the things that have demotivated me...that have discouraged ..., and that has pushed me to think that now I have to think of some other alternatives....

From T1's response, it can be revealed that he was found to be unhappy and demotivated due to tight holidays and no longer leaves. He further says that he is provided with 12 days as holidays in a year. If he remains absent for more than a day in a month, his salary is deducted, due to which he says that he is extremely demotivated and thus he is thinking of finding other better jobs where he gets more holidays and leaves. In this regard, T2 shared:

Well...ah.... I am not considered on leaves, apart from public holidays...sometimes I may be sick, or I may have an emergency...so I ask for leave. Still, the principal denies telling me to come with a doctor's prescription or other proofs..... frustrating ....

The utterance made by respondent B above is truly empathetic. He says that he is not granted more than already fixed leaves, except for public holidays. He tells the fact that the principal denies granting him heaves even if he knows the teacher has some emergency. He becomes so cruel that he asks him to come with a doctor's prescription if he is falling sick actually. In this respect, T3 articulated:

If I take leaves, our salary is deducted ...there is no payment of that day.... sometimes we can have household affairs, at such time we need to take leave as well...this disappoints me....

From his response, it is vivid that he was also demotivated because of the rigidity in holidays and leaves. The teacher respondent in an interview says that if he takes a leave, his remuneration of its equivalent day is deducted. He says in a reflective manner that he can have some household chores to be done and, therefore, wants to be granted leaves, but pathetically, the principal disagrees. Similarly, T4 also articulated: 
Well.... ah... holidays are not given as per required.... if I have some urgency, I should go there without telling the administration by deducting my salary of a day ...if I stayed longer, likely to be waved goodbyes......horrible...

This utterance of T4 also expresses the similar idea that he was demotivated. Even if he has got into any personal troubles and asks leaves, the administration seems indifferent. Therefore, he says that he does not inform the concerned people because they never understand and consider his leaves without deducting the salary.

From the abovementioned analyses based on data excerpts, it can be interpreted that all the teachers were found to be demotivated due to the fewer holidays. They said that their principals and administrations did not listen to and understand them if they asked for leaves, let alone long leaves; if they had to take long leaves, their job was at risk. Thus, it is clear that if the teachers teaching at institutional schools are given leaves equivalent to government teachers, they are sure to be motivated to some point in giving their best to the students.

\subsection{Job insecurity}

Every teacher wants to feel secure in teaching. But, the teachers teaching at institutional academics were found to be expressing the idea that they are not feeling secure in teaching. They said that they were demotivated. Regarding this, T1 said:

Well, in the institutional sector, employee's relationship with the administrators is quite dubious and doubtful for few reasons ...school administration thinks of using teacher till the day he is productive ......right after he gets older ...and he turns a bit unproductive ...the school administrators think about firing him and hiring new teachers... mm... yes...ah......I do have a good relationship, but I am not satisfied with the policy they implement at the school.

The utterance made by $\mathrm{T} 1$ highlights the fact that the relationship between the administration and the teacher is dubious because he says that the school tries to use him till the day he is energetic and active. Still, when he is incapable of discharging his duty due to some personal problems and turns older, the school administration thinks of firing him and hiring new teachers. In a similar vein, T2 articulated:

....so for me the facilities that I am provided are not sufficient ......... I am planning to get another profession so that at least I can secure my career later on.... teaching profession makes me happy...the main thing is that we have to go through the day-to-day problems. That's why....

From T2's utterance above, it can be conferred that he was also found to be demotivated due to the fear of insecurity in institutional schools. He says that the administrators have such a cruel policy that they keep using the teachers until they are productive, but they are fired and go for hiring other new teachers the day they are unproductive. His story touched my heart because I am also an institutional teacher somewhere. Furthermore, in the same regard, T3 shared:

Well......ah... I am not very satisfied. I am thinking about being a permanent teacher because for my own comfort...because all the time there is do or die, like hire and fire. I think it's not good to hang on the institutional job all the time....so very soon I plan to be a permanent teacher....

From T3's narrative above, it can be revealed that he was also found to be demotivated due to no guarantee of future at institutional schools. He says that he plans to be a permanent teacher thinking that he will be secure. He adds that institutional teachers like him do not feel comfortable because they never know when the school starts firing them from the job. Regarding the same theme, T4 also commented:

Umm...well... the school administrators are always dominating us this way or the other, and if we speak against what they say, we are likely to be boycotted from that school...upsetting....

T4's story is truly poignant. He says that if he speaks against the school administrators, they are dissatisfied and seem to boycott him due to the fear of which he has to teach as if he is a servant of a master.

The narratives of all the teachers presented above exhibit the fact that the institutional teachers were found to be no happier in teaching because they said that they would be fired from the job if they spoke against the administrators. Even if their ideas are noteworthy, they do sideline them. From this, it can be urged that the institutional schools should create such a conducive environment where the teachers could feel secure and make sure that they are working in a safe zone.

\subsection{Students' Disruptive Behavior}

Students' disruptive behaviors are the activities shown by the students which disturb the teaching and learning process. This theme is derived from T3's and T4's anecdotes. He said that he had been badly laughed at by the students because of his habit of saying 'YES, YES' and wrong pronunciations of English words. Regarding this, he articulated:

Due to the way I pronounce the words and the way I teach my students, I am badly laughed at ... they tease me by saying 'Yes' 'Yes' because I have the habit of saying 'Yes' 'Yes' repeatedly.... 
From T3's anecdote above, it can be said that he was found to be demotivated due to the disruptive behaviors of the students. He says that the students frequently tease him because he says that he has the habit of repeatedly saying 'YES' and adds that sometimes he misspells and mispronounces English words. In such a situation, the students mock him, which he dislikes and has realized now. He goes on to tell the fact that the students at government schools are poor at English, so the teachers can dominate the students, control them, and bring them on a disciplined track, but the students at institutional schools are good at English. Therefore, they do not obey the teachers and become disruptive. Due to this, he says that he is demotivated to teach at institutional schools. In a similar vein, T4 commented:

.... sometimes, due to the students' disruptive behaviors, I feel frustrated because they show angry reactions whenever I try to bring them under my control....

T4 also expresses the similar idea that due to the quarrelsome manners of the students, he was found to be demotivated. He says that the students do not obey him if he asks them to be quiet and asks them not to disturb the class; instead, he says that they are ready to challenge and threaten him, which is frustrating to him.

From the narratives above, it is true to say that the teachers were found to be demotivated because of students' disruptive behaviors that they show off in the classroom. They said that whenever they asked them to be quiet and asked them not to be disturbing, they would give an angry reaction and were ready to take violent actions against the teachers. Therefore, it can be said that students should be psychologically brought on the right track; if done so, the teachers may not feel demotivated and frustrated in teaching.

\subsection{Task pressure}

A large workload is a serious factor in teaching. It means the situation where the teachers are supposed to work harder than necessary. Regarding this theme, the teachers' narratives express that they were demotivated due to a heavy workload. All the teachers said that the school administrators became happy only when they would teach without compromising their health and personal life, staying longer at the schools. Regarding this, T2 mentioned,

...... am working here not only as a teacher but also as a curricular academic in charge. I have to work here from morning to evening...almost 12 hours... as I have been working here as an in-charge, .... I have to go through several problems......for me going together as a leader, incharge, and supervising other teachers, motivating them to carry on teaching is very difficult

Based on T2's story, it can be said that he was found to be demotivated due to the heavy workload. He says that he has dual responsibilities - a teacher and academic coordinator, and therefore, he has to fulfill two jobs simultaneously, which he says he cannot. He further says that if he is given a single responsibility, he will pay due attention. He honestly states that he does not like being given dual responsibilities. To him, this sort of act is troublesome. Further, in the same regard, T3 articulated:

...Well....as I spend almost 8/9 hours .... I have to get there at 9 am and get back only after $5 \mathrm{pm}$.......my job is not only to teach my subject....... but if any other teachers are absent, I should go and teach.... I cannot get leisure time...

From the narrative of $\mathrm{T} 3$, it can be stated that he was found to be demotivated due to the overworking hours at schools. He says that he does not get a chance to rest even at leisure, and the administrators tell him to take any subjects where the teacher is absent. In such a situation, he says that even if he does not have good command over the subject matter, he has to teach and expresses dissatisfaction that he may not be good at all subjects, however, the principal tells him it's the platform to learn and earn. In this regard, T4 also shared:

Well, ... ah....and also what I don't like about this school is that we are called even on Saturdays to do the extra jobs, and if we deny, they ask us the reason why......that truly frustrates me, if I had not had compulsion, I would have given it up and gone somewhere, where there would have been fewer workloads .... hmm....

This narrative above deals with the fact that T4 was also demotivated due to heavy workloads. He says that the school calls him to be at school even on Saturdays to do the rest of the jobs that have been left the previous day. And, he goes on to tell that if he does not go, the administration tortures him by asking the reasons behind it. So, he says that if he had not had compulsion, he would have given it up and have joined the other jobs.

To conclude the narratives of all the teachers above, it is coincided that the teachers teaching at institutional academics were demotivated due to long and heavy working hours. Most teachers said that the schools called them even on Saturdays and added that if they did not go, they would be taken actions due to which they feel disappointed to remain teaching. Therefore, what can be said is that if the teachers teaching at institutional schools are pleased with light workloads and required working hours, they are likely to be motivated. As a result, they can be teaching with full devotion and commitment. 


\section{Conclusion}

The findings of this study revealed that Nepalese EFL teachers in private schools are demotivated both intrinsically and extrinsically. The factors that demotivate these teachers include low wages, lack of professional development events, students' disruptive behaviors, job insecurity, and fewer holidays - known as academic factors.

Teachers' demotivation is considered to be a major obstacle in making the teaching and learning process more effective. And therefore, the institutional EFL teachers should be motivated through satisfactory pay, organizing different professional events and valuing them in society.

Finally, it can be concluded that EFL teachers' motivation is a must for professional development during the pandemic and much before too. If the English teachers are not motivated to teach, they are unlikely to teach assiduously. And thus, it is vital to take all the demotivating factors into account to bring about a paradigm shift in teaching and learning processes in the realm of the whole education system in Nepal.

\section{References}

[1] Bishay, A. (1996). Teacher motivation and job satisfaction: A study employing the experience sampling method. A Journal of Undergraduate Science, 3, 147- 155

[2] Blaskova, M. \& Basko, R. (2013). Motivation of university teachers and its connections. Human Resource Management and Economics, 7 (2).

[3] Bredson, P. \& Johansson, O. (2000). The school principal's role in teacher professional development. Journal of In-service Education, 26(2), 385- 401.

[4] Dornyei, Z. \& Ushioda a, E. (2001). Teaching and researching motivation (2nd ed.). New York, NY: Longman.

[5] Gheralis- Roussos, E. (2003). The motivation of English language teachers in Greek secondary schools. An unpublished doctorate dissertation, University of Nottingham.

[6] Han, J. \& Yin, H. (2016). Teacher motivation: Definition, research, development and implications for teachers. Teacher Education and Development, 3, 1-18.

[7] Han, J. \& Yin, H. (2016 a). Teacher motivation: Definition, research, development and implications for teachers. Teacher Education and Development, 3, 1-18.

[8] Han, J. \& Yin, H. (2016 b). Teacher motivation: Definition, research, development and implications for teachers. Teacher Education and Development, 3, 1-18

[9] Hettarachchi, S. (2013). English Language teacher's motivation in Sri Lankan public schools. Journal of Language Teaching and Research, $4(1), 1-11$.

[10] Hennessy, J. \& Lynch, R. (2017). I chose to become a teacher: Exploring the factors influencing teaching choice amongst pre- service teachers in Ireland. Asia- Pacific Journal of Teacher Education, 45 (2), 106- 125.

[11] Hettarachchi, S. (2013 b). English Language teacher's motivation in Sri Lankan public schools. Journal of Language Teaching and Research, $4(1), 1-11$.

[12] Huseman, C. R., Hatfield and Miles, W. E. (1987). A new perspective on equity theory: The equity sensitivity construct. Academy of Management, $12(2)$.

[13] Jesus, S. N. \& Lens, W. (2005). An integrated model for the study of teacher motivation. Applied psychology: International Review, 54(1), $119-134)$

[14] Kiziltepe, Z. (2008). Motivation and Demotivation of university teachers. Teachers and Technology, 14, $515-530$.

[15] Kumar, R. (2005). Research methodology: A step by step guide for beginners (2nd ed.). India: Pearson Education.

[16] Monyatsi, P.P. (2006). Motivating the motivators with developmental teacher appraisal. Journal of Social Science, 13(2), 101-107

[17] Nadif, B. \& Benattabou, D. (2021). Rethinking the Insights from Good Language Learner Studies: Moroccan Learners of EFL as a Case Study. International Journal of Linguistics, Literature and Translation, 4 (3), 61-73. http://dx.doi.org/10.32996/ijltt.2021.4.3.7

[18] Nawaz, N. \& Yasin, H. (2005). Determinants of motivation in teachers: A study of institutional secondary school's chain networks in Bahawalpur. Journal of Education and Practice, 6(4), 55- 59.

[19] Pan, V. \& Say, S. (2017). Investigation of the factors influencing teaching professional choices of pedagogical formation trainees. The Turkish Online Educational Technology.

[20] Pant, B. (2018). English Language teachers' motivation in professional development. An unpublished master's thesis, TU, Kirtipur.

[21] Safari, I. (2021) Relationship Between Iranian EFL Teachers' Self-Efficacy and Their Burnout Level in Universities and Schools. International Journal of Foreign Language Teaching \& Research, 26-38.

[22] Sinclair, C. (2008). Initial and changing student-teacher motivation and commitment to teaching. Asia Pacific Journal of Teacher Education, 36, 79- 104.

[23] (PDF) Teacher motivation: Definition, research development. https://www.researchgate.net/publication/305924536_Teacher_motivation_Definition_research_development_and_implications_for_teachers 